\title{
Hawaïan Birdlife
}

\section{PROPERTY}

\section{UNIVERSITY OF HAWAII PRESS}





\section{Hawaïan Birdlife}

SECOND EDITION

Andrew J. Berger

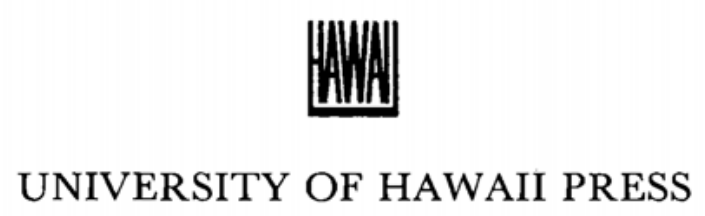

HONOLULU 
Copyright $(\subset) 1972,1981$ by The University Press of Hawaii

All rights reserved

First edition 1972

Second edition 1981

Printed in the United States of America

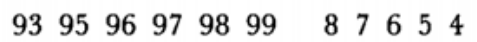

\section{Library of Congress Cataloging in Publication Data}

Berger, Andrew John, 1915-

Hawaiian birdlife.

Bibliography: p.

1. Birds-Hawaii. I Title.

QL684.H3P47 1981

598.29969

$80-26332$

ISBN 0-8248-0742-1

University of Hawaii Press books are printed on acid-free paper and meet the guidelines for permanence and durability of the

Council on Library Resources 
ALFRED M. BAILEY

EDWIN H. BRYAN, JR.

ALEXANDER WETMORE 
